Copyright (C) 2015 by Academic Publishing House Researcher

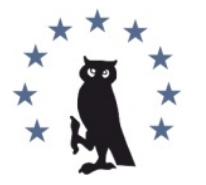

Published in the Russian Federation

European Researcher

Has been issued since 2010 .

ISSN 2219-8229

E-ISSN 2224-0136

Vol. 97, Is. 8, pp. 539-559, 2015

DOI: $10.13187 /$ er.2015.97.539

www.erjournal.ru

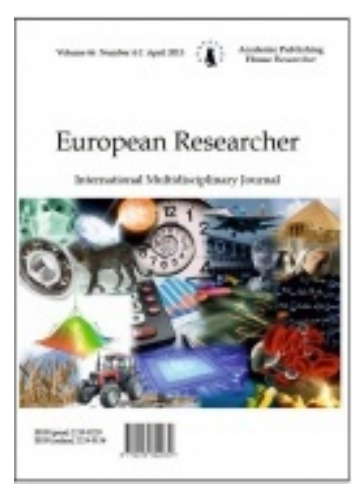

Pedagogical sciences

Педагогические науки

UDC 37

\title{
Comparative Analysis of Students' Media Competences Levels
}

\author{
Alexander Fedorov \\ Anton Chekhov Taganrog Institute, branch of Rostov State University of Economics, \\ Russian Federation \\ Professor, Doctor of Pedagogy \\ E-mail: mediashkola@rambler.ru
}

\begin{abstract}
This article analyzed the results of survey of university students' media literacy competence (on the base of a classification of indicators of media literacy competence of the audience as an effective tool for comparative analysis of the levels of development of media competence of students of the control and experimental groups): the level of media competence of students who have a one-year training course in the framework of media literacy education courses four times higher than in similar indicators in the control group. Analysis of the results of this survey confirmed the general trend of media contacts of student audience - its orientation to entertainment genres of audiovisual media, visually appealing; positive, active, unmarried, childless, educated, highly qualified characters (primarily - male characters) aged 19 to 35 years. These heroes are characteristic optimism, independence, intelligence, emotion. They have an excellent command of the life situation and have a positive impact on the development progress of the plot of a media text.

Keywords: survey, analysis, media, media texts, media education, media literacy, media competence, students.

\section{Introduction}

Based on the media literacy education technology (Fedorov, 2004, p. 43-51), I had media literacy education lessons in pedagogical university. My objective was to track changes in the levels of students' media competence in the control and experimental groups.

Ascertaining levels of media competence of students based on indicators of the classification of media competence of the individual, by which I mean the sum of its motives, knowledge, skills, abilities (motivation, contact, information, perceptual, evaluation, practice and activity, creative) promoting the use and critical analysis, evaluation and transfer of media texts in different types, forms and genres, the analysis of complex processes of media functioning in society.
\end{abstract}




\section{Materials and methods}

In accordance with this interpretation of students' media competence I created the five main blocks of questions and tasks:

1) the block of questions (closed-type profile) to identify levels of motivation indicator of audience's media competence (genre, theme, psychological, therapeutic, emotional, epistemological, moral, intellectual, creative and aesthetic motifs on by contact of an audience with a media texts);

2) the set of questions (closed-type profile) to identify levels of contact indicator (frequency of contacts with various types of media) the development of the audience's media competence;

3) the set of questions (closed-type test) to detect the level of information index (knowledge of terminology, history and theory of media culture) development of the audience's media competence;

4) the block of analytical tasks for detecting levels of evaluation index (based on various levels of perceptual indicator) development of the audience's media competence;

5) the block of creative tasks for detecting levels of the audience's creative media competence.

90 students of the faculty of psychology and social pedagogy involved in my experiment at Anton Chekhov Taganrog Institute (the age of students: 20-21 years): 45 students (14 boys and 31 girl) of the control group, in which were no class of media education cycle, and 45 students (14 boys and 31 girls) of the experimental group, in which the media education cycle was conducted during the academic year. My research showed that no significant difference in the levels of development of media competence of students of the control and experimental groups were observed in the beginning of the education year. And the levels of development of students' media competence recorded at begin and the end of the education year in the control group were approximately the same.

The ratio of boys and girls in the control and experimental groups, in our opinion, is typical of the Russian pedagogical universities, which for decades has been male students consistently are a minority ( $10 \%$ to $30 \%$ of the composition of the study groups).

\section{Results}

Analysis Table 1 shows that a high level of motivation indicator of media competence, that is a wide range of genres, thematic, emotional, epistemological, hedonistic, intellectual, psychological, creative, aesthetic reasons (including: selection of different genre and thematic spectrum of media texts with the mandatory inclusion of non-entertainment genres the desire for philosophical / intellectual, aesthetic discussion / dialogue with the creators of media text, criticism of their position; to identify, empathy, the desire for aesthetic experience, to obtain new information, to validate their competence in various fields of life and media culture; to search for educational materials, scientific and research purposes, etc.) actually found only $11 \%$ of the students in the control group.

Table 1: The classification of the identified levels of motivation indicator of students' media competence in the control and experimental groups

\begin{tabular}{|c|c|c|c|c|c|c|c|}
\hline \multirow[t]{2}{*}{ № } & \multirow{2}{*}{$\begin{array}{l}\text { Number of } \\
\text { levels of } \\
\text { the } \\
\text { motivation } \\
\text { al } \\
\text { indicator: }\end{array}$} & \multicolumn{3}{|c|}{ Students from the control group: } & \multicolumn{3}{|c|}{$\begin{array}{l}\text { Students from the experimental } \\
\text { groups: }\end{array}$} \\
\hline & & 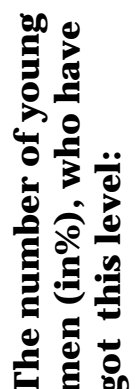 & 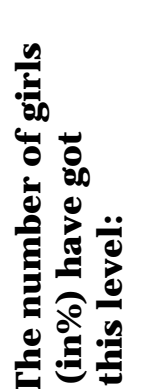 & 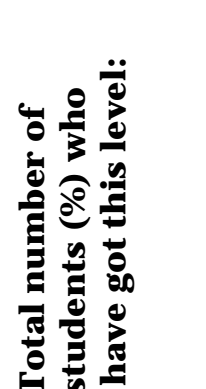 & 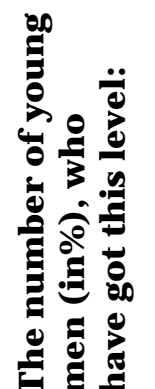 & 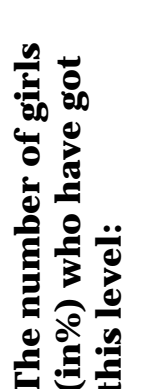 & 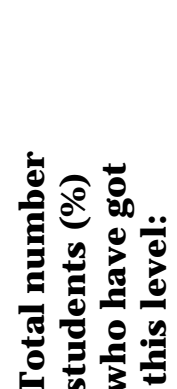 \\
\hline $\mathbf{1}$ & High level & 0,00 & 16,13 & 11,11 & 14,28 & 29,03 & 24,44 \\
\hline
\end{tabular}




\begin{tabular}{|l|l|c|c|c|c|c|c|}
\hline $\mathbf{2}$ & $\begin{array}{l}\text { Average } \\
\text { level }\end{array}$ & 21,43 & 35,48 & $\mathbf{3 1 , 1 1}$ & 35,71 & 48,39 & $\mathbf{4 4 , 4 4}$ \\
\hline $\mathbf{3}$ & Low level & 78,57 & 48,39 & $\mathbf{5 7 , 7 8}$ & 50,00 & 22,58 & $\mathbf{3 1 , 1 1}$ \\
\hline
\end{tabular}

The identified levels of motivation indicator of students' media competence in the experimental groups (past media education program course) exceed twice that in the control group. At the same time gender difference was clearly manifested in the control and experimental groups: the number of women who have a high level of motivation indicator of media literacy, significantly higher than the number of boys. In contrast, among boys revealed significantly more respondents who found a low level of motivation indicator of media competence (i.e. narrow spectrum of genre, theme, emotional, hedonistic, psychological reasons, including: the choice of only the entertainment genre and thematic spectrum of media texts, the desire for compensation, pursuit the psychological "treatment", the desire for thrills, the desire for recreation, entertainment and the absence of aesthetic, intellectual, creative motives of contacts with media texts).

Thus, the comparison of students' media motivation in the control and experimental groups to some extent show the effectiveness of media education curriculum for students of experimental group.

Table 2: The classification of the identified levels of contact indicator of students' media competence in the control and experimental groups (type of media: press)

\begin{tabular}{|c|c|c|c|c|c|c|c|}
\hline \multirow[t]{2}{*}{ № } & \multirow{2}{*}{$\begin{array}{l}\text { Numb } \\
\text { er of } \\
\text { levels } \\
\text { of the } \\
\text { conta } \\
\text { ct } \\
\text { indica } \\
\text { tor: }\end{array}$} & \multicolumn{3}{|c|}{ Students from the control group: } & \multicolumn{3}{|c|}{$\begin{array}{l}\text { Students from the experimental } \\
\text { groups: }\end{array}$} \\
\hline & & 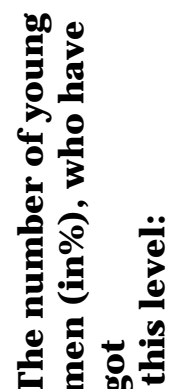 & 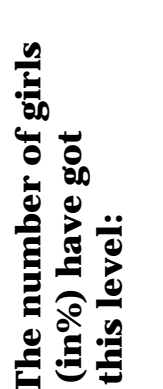 & 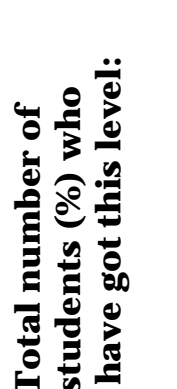 & 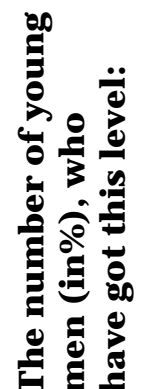 & 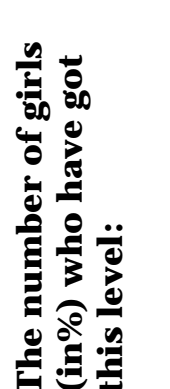 & 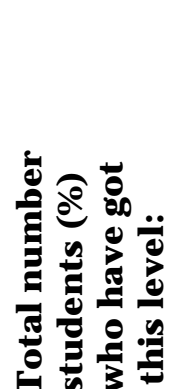 \\
\hline 1 & $\begin{array}{l}\text { High } \\
\text { level }\end{array}$ & 0,00 & 0,00 & $\mathbf{0 , 0 0}$ & 14,28 & 3,22 & 6,67 \\
\hline 2 & $\begin{array}{l}\text { Avera } \\
\text { ge } \\
\text { level }\end{array}$ & 50,00 & 54,84 & 53,33 & 42,86 & 58,06 & 53,33 \\
\hline 3 & $\begin{array}{l}\text { Low } \\
\text { level }\end{array}$ & 50,00 & 45,16 & 46,67 & 42,85 & 38,70 & 39,99 \\
\hline
\end{tabular}

Data analysis of table 2 shows that a big difference exists between students of the control and experimental groups in the area of the press reading. About half of both groups found the average level of the contact indicator (read the press several times a week) the development of media competence. A significant gender differences in this regard have also been observed. However the contact indicator is not the main indicator of media competence. Undoubtedly, a person who is not in contact with media has not the high level of media competence. But the highest level of television viewing, listening to the radio, surfing the Internet or reading the press cannot guarantee a high level of media competence, if a person, for example, has poor analytical skills. 
Table 3: The classification of the identified levels of contact indicator of students' media competence in the control and experimental groups (type of media: radio)

\begin{tabular}{|c|c|c|c|c|c|c|c|}
\hline \multirow[t]{2}{*}{ № } & \multirow{2}{*}{$\begin{array}{l}\text { Number } \\
\text { of levels } \\
\text { of the } \\
\text { contact } \\
\text { indicator: }\end{array}$} & \multicolumn{3}{|c|}{ Students from the control group: } & \multicolumn{3}{|c|}{$\begin{array}{l}\text { Students from the experimental } \\
\text { groups: }\end{array}$} \\
\hline & & 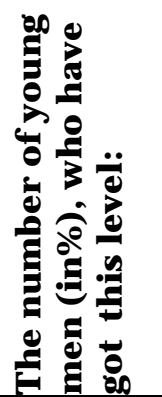 & 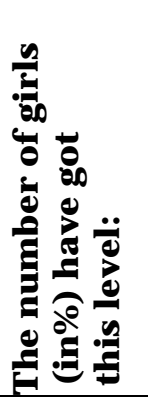 & 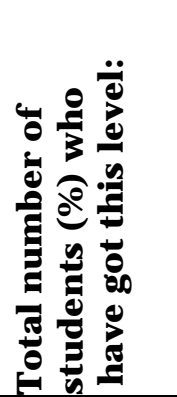 & 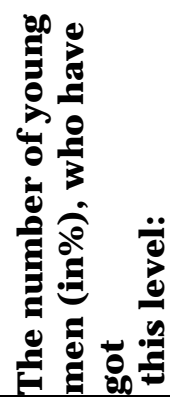 & 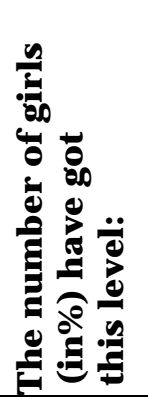 & 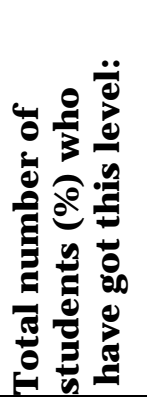 \\
\hline 1 & High level & 42,86 & 45,16 & 44,44 & 42,86 & 74,19 & 64,44 \\
\hline 2 & $\begin{array}{l}\text { Average } \\
\text { level }\end{array}$ & 21,43 & 25,81 & 24,44 & 35,71 & 9,68 & 17,78 \\
\hline 3 & Low level & 35,71 & 29,03 & 31,11 & 21,42 & 16,12 & 17,77 \\
\hline
\end{tabular}

Analysis Table 3 shows that there are certain differences between the students of the control and experimental groups in relation to listening to the radio. $64 \%$ of respondents from the experimental group have high (daily) the level of listening to the radio, but in the control group only $44 \%$. Compared with control group, the experimental group is almost half of the respondents with low (once a month or less) level of contact with the radio.

Table 4: The classification of the identified levels of contact indicator of students' media competence in the control and experimental groups (type of media: TV)

\begin{tabular}{|c|c|c|c|c|c|c|c|}
\hline \multirow[t]{2}{*}{ № } & \multirow{2}{*}{$\begin{array}{l}\text { Number of } \\
\text { levels of the } \\
\text { contact } \\
\text { indicator: }\end{array}$} & \multicolumn{3}{|c|}{ Students from the control group: } & \multicolumn{3}{|c|}{$\begin{array}{l}\text { Students from the experimental } \\
\text { groups: }\end{array}$} \\
\hline & & 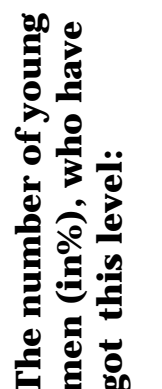 & 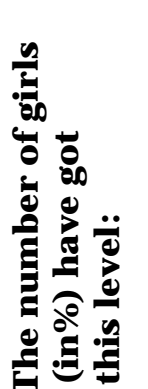 & 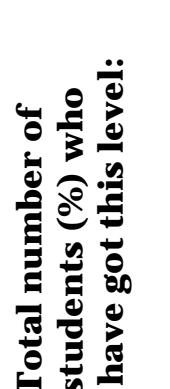 & 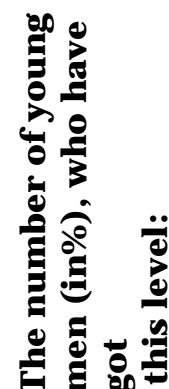 & 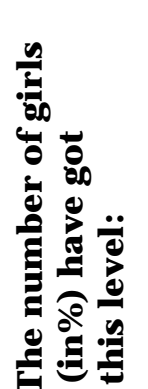 & 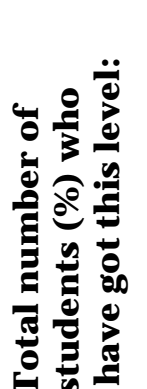 \\
\hline 1 & High level & 71,43 & 74,19 & 73,33 & 71,43 & 64,52 & 66,67 \\
\hline 2 & $\begin{array}{l}\text { Average } \\
\text { level }\end{array}$ & 14,28 & 12,90 & 13,33 & 28,57 & 16,13 & 20,00 \\
\hline 3 & Low level & 14,28 & 12,90 & 13,33 & 0,00 & 19,35 & 13,33 \\
\hline
\end{tabular}

Analysis of Table 4 gives an indication of the fact that viewing among students from control and experimental groups no big differences in relation to TV. Over $66 \%$ of these both students groups watching TV daily, from $13 \%$ to $20 \%$ - several times per week. And only $13 \%$ students for control and experimental groups watching television a few times a month or less. At the same time symptomatic of gender differences cannot be detected.

I believe that the lack of progress in increasing the frequency of television viewing in the experimental group is not a fault of the experiment, as I initially did not set a goal to increase the contact indicator of students' audience. As shown by further analysis of the experimental results, a slightly higher level of TV viewing in the control group did not contributed to raising the analytical level indicator of students' media competence. 
Table 5: The classification of the identified levels of contact indicator of students' media competence in the control and experimental groups (type of media: Internet)

\begin{tabular}{|c|c|c|c|c|c|c|c|}
\hline \multirow[t]{2}{*}{ № } & \multirow{2}{*}{$\begin{array}{l}\text { Number } \\
\text { of } \\
\text { levels of } \\
\text { the } \\
\text { contact } \\
\text { indicator: }\end{array}$} & \multicolumn{3}{|c|}{ Students from the control group: } & \multicolumn{3}{|c|}{$\begin{array}{l}\text { Students from the experimental } \\
\text { groups: }\end{array}$} \\
\hline & & 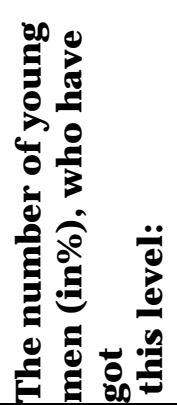 & 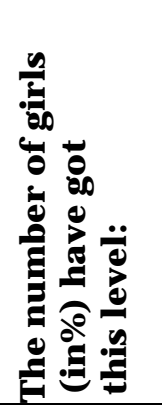 & 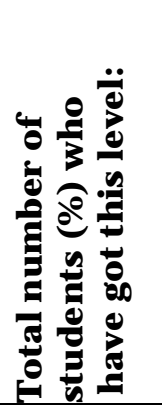 & 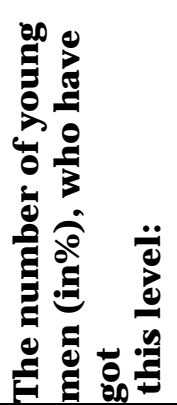 & 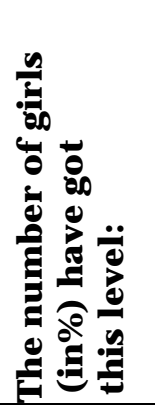 & 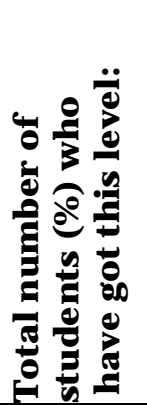 \\
\hline 1 & High level & 00,00 & 6,45 & 4,44 & 14,28 & 6,45 & $\mathbf{8 , 8 9}$ \\
\hline 2 & $\begin{array}{l}\text { Average } \\
\text { level }\end{array}$ & 35,71 & 6,45 & 15,55 & 21,43 & 22,58 & 22,22 \\
\hline 3 & Low level & 57,14 & 54,83 & 55,55 & 57,14 & 61,29 & 57,99 \\
\hline
\end{tabular}

$24.44 \%$ of the students in the control group (7.14 \% of boys, girls $32.26 \%$ ) and $8.89 \%$ of students in the experimental group (7.14 \% of boys, girls $9.68 \%$ ) never use the Internet. Unfortunately, the level of contacts between Russian students with the Internet still leaves much to be desired: only between $4 \%$ and $9 \%$ of students in the control and experimental groups visit the Internet daily and $15 \%$ to $23 \%$ - on a weekly basis. But more than half of the students from control and experimental groups, visit the Internet site several times a month or less, and from $9 \%$ to $24 \%$ of the students do not come to the Internet at all. The majority of students' interactive contact takes place in the university / internet cafes, but not at home.

The levels' difference in the control and experimental groups is small, but the analysis of table 5 showed that gender differences in relation to contacts with the Internet are available. Boys with their traditional propensity for technical innovations somewhat more active in a web surfing than girls, which is correlated with the results of similar surveys conducted previously by various organizations (eg, see: Education \& Culture, 2000).

Table 6: The classification of the identified levels of contact indicator of students' media competence in the control and experimental groups (type of media: video/ PC games)

\begin{tabular}{|c|c|c|c|c|c|c|c|}
\hline \multirow[t]{2}{*}{ № } & \multirow{2}{*}{$\begin{array}{l}\text { Number of } \\
\text { levels } \\
\text { of the } \\
\text { contact } \\
\text { indicator: }\end{array}$} & \multicolumn{3}{|c|}{ Students from the control group: } & \multicolumn{3}{|c|}{$\begin{array}{l}\text { Students from the experimental } \\
\text { groups: }\end{array}$} \\
\hline & & 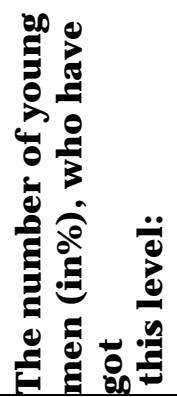 & 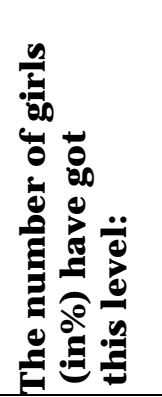 & 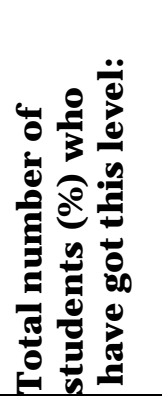 & 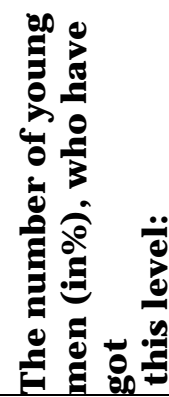 & 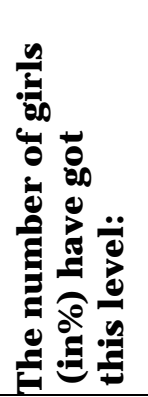 & 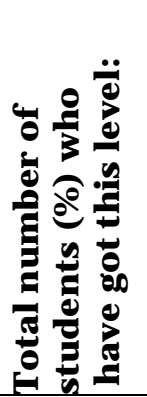 \\
\hline 1 & High level & 14,28 & 6,45 & 8,89 & 7,14 & 3,22 & 4,44 \\
\hline 2 & $\begin{array}{l}\text { Average } \\
\text { level }\end{array}$ & 42,86 & 6,45 & 17,78 & 35,71 & 19,35 & 24,44 \\
\hline 3 & Low level & 35,71 & 58,06 & 51,11 & 49,99 & 41,93 & 44,45 \\
\hline
\end{tabular}

$22.22 \%$ of the students in the control group (7.14 \% boys, $29.03 \%$ girls) and $26.67 \%$ of students in the experimental group ( $7.14 \%$ boys, $35.48 \%$ girls) never play video / computer games. 
Of course, the frequency of contacts of students with a video / computer games can in no way be tangible proof of their media competence. In my view, even the opposite: too frequent habit of playing with the computer takes away from the time for human contact with other kinds of media. However, analysis of table 6 shows that the level of contacts of students from control and experimental group is comparable, and only $4 \%-9 \%$ of students have the high level of this type of contacts. But more than half of the students play computer games several times a month, and $22 \%$ - $26 \%$ do not play them at all.

The gender difference in relation to computer games is quite distinct, as the number of boys fans of such activities at least twice the number of girls, which again corresponds to the world practice of similar sociological research. The majority of popular computer games based on the theme of violence («Doom», etc.) with the dominance of the male computer players.

Table 7: The classification of the identified levels of contact indicator of students' media competence in the control and experimental groups (an average of all of the above types of media)

\begin{tabular}{|c|c|c|c|c|c|c|c|}
\hline \multirow[t]{2}{*}{ № } & \multirow{2}{*}{$\begin{array}{l}\text { Number of } \\
\text { levels } \\
\text { of the } \\
\text { contact } \\
\text { indicator: }\end{array}$} & \multicolumn{3}{|c|}{ Students from the control group: } & \multicolumn{3}{|c|}{$\begin{array}{l}\text { Students from the experimental } \\
\text { groups: }\end{array}$} \\
\hline & & 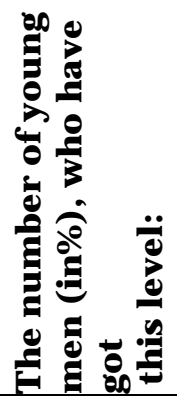 & 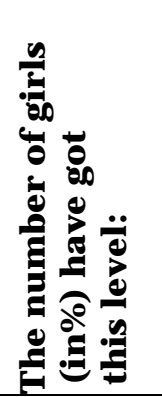 & 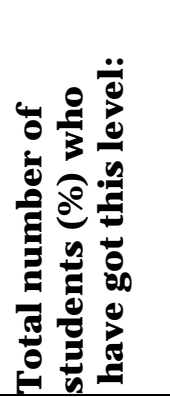 & 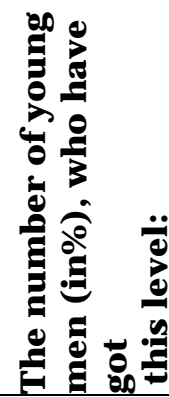 & 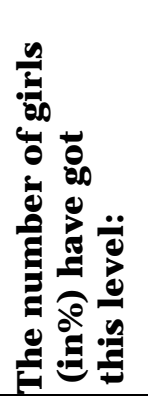 & 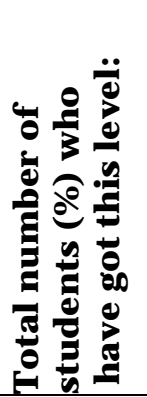 \\
\hline 1 & High level & 25,71 & 26,45 & 26,22 & 14,28 & 0,00 & 4,44 \\
\hline 2 & $\begin{array}{l}\text { Average } \\
\text { level }\end{array}$ & 32,86 & 21,29 & 24,89 & 64,28 & 93,55 & $\mathbf{8 4 , 4 4}$ \\
\hline 3 & Low level & 38,57 & 40,00 & 39,55 & 21,43 & 6,45 & 11,11 \\
\hline
\end{tabular}

Thus, only $26.22 \%$ of the students from the control group and $4.44 \%$ from the experimental group showed a high level of the contact indicator by several kinds of media in general. However, I should not forget that this result is due to a low degree of contact of the audience with the Internet and computer games (where the low level of contacts found more than half of the respondents in both groups). But $73.33 \%$ of the surveyed students ( $71.43 \%$ boys and $74.19 \%$ girls) in the control group and $66.67 \%$ of the students from the experimental group $(71.43 \%$ boys and $64.52 \%$ girls) said that they watch TV every day. Pretty high was and students' contact level in relation to listening to the radio ( $44 \%$ to $64 \%$ of respondents with high level of exposure to this type of media).

I can conclude that $50 \%$ to $89 \%$ of the students have average and high contact indicator, which in itself, as I have noted, cannot be considered as a basic indicator for determining the level of media competence of the respondents as a whole.

After that students were asked 30 questions divided into blocks of 10 questions each. One block consisted of questions relating to the terminology of media / media culture, the second the history of media / media culture, the third - the theory of media / media culture.

For one correct answer for each question the student received 1 point. Thus, the maximum number of points that could gain the student as a result of the test was 30 .

The high level of information index of media competence: students who were able to give a $80 \%$ to $100 \%$ of correct answers (from 24 to 30 points);

The average level of information index of media competence: students who were able to give a $50 \%$ to $80 \%$ correct answers (from 15 to 23 points);

The low levels of information index of media competence: students who were able to give less $50 \%$ correct answers (from 0 to 14 points).

The test results are summarized in the table 8. 
Of course, testing of students according to our questions was not without vulnerabilities. On the one hand, students retain the ability to intuitive answers - by exclusion the most questionable choices, and the correct answer has a probability of $25 \%$, then there is one correct answer from four possible. On the other hand, testing could not give guarantees against cheating and prompting students to each other. However, the test results were verified with the results of our surveys and oral interviews, which greatly helped to ensure that they are correctly reflected in the overall outcome of students' knowledge (in the control and experimental groups).

Analysis of the table 8, in our opinion, clearly demonstrates the effectiveness of media education activities conducted with the students of the experimental group during the year. A high level of media competence information index (from $80 \%$ to $100 \%$ of correct answers to questions related to the terminology, history and theory of media / media culture) showed $95 \%$ of students in the experimental groups, while this per cents in the control group of respondents Were only $13 \%$.

Low levels of information index (less than $50 \%$ correct answers) was not seen at all in the experimental group, whereas in the control group 37\% of students were at low levels of information index.

Gender differences in responses between students showed that girls generally have a large amount of knowledge about the terminology of the theory and history of media / media culture. $13 \%$ of students from the control group showed a high level of media competence indicator information without having to visit any media educational activities. And it can be assumed that this level has been reached by them at the expense of self and / or family upbringing.

Table 8: The classification of the identified levels of information indicator of students' media competence in the control and experimental groups

\begin{tabular}{|c|c|c|c|c|c|c|c|}
\hline \multirow[t]{2}{*}{ № } & \multirow{2}{*}{$\begin{array}{l}\text { Number of } \\
\text { levels of the } \\
\text { information } \\
\text { indicator: }\end{array}$} & \multicolumn{3}{|c|}{ Students from the control group: } & \multicolumn{3}{|c|}{$\begin{array}{l}\text { Students from the experimental } \\
\text { groups: }\end{array}$} \\
\hline & & 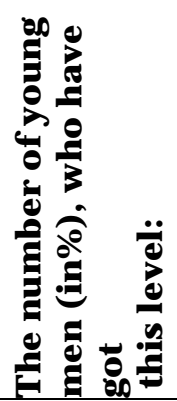 & 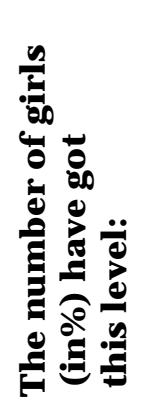 & 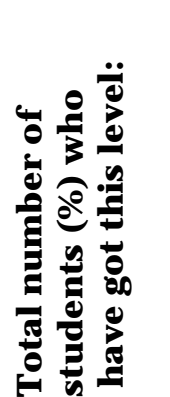 & 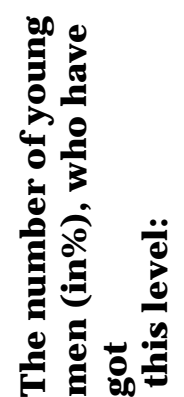 & 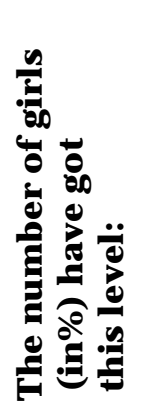 & 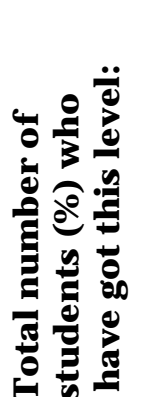 \\
\hline 1 & High level & 7,14 & 16,13 & 13,33 & 92,86 & 96,77 & 95,55 \\
\hline 2 & $\begin{array}{l}\text { Average } \\
\text { level }\end{array}$ & 28,57 & 58,06 & 48,89 & 7,14 & 3,23 & $\mathbf{4 , 4 4}$ \\
\hline 3 & Low level & 64,29 & 25,81 & 37,78 & 0,00 & 0,00 & $\mathbf{0 , 0 0}$ \\
\hline
\end{tabular}

The data in Table 9 shows how the distributed right / wrong answers of students from control and experimental groups on various types of test information knowledge in the field of media / media culture.

Analysis of the data in Table 9 shows that students experienced the greatest difficulties when answering the questions of the text relating to the history of media / culture media (the number of incorrect responses was generally about $50 \%$ in the control group, while in the experimental group it was slightly higher). 
Table 9: The results of testing of students in the control and experimental groups (levels of information indicator of media competence)

\begin{tabular}{|c|c|c|c|c|c|c|c|}
\hline \multirow{2}{*}{$\begin{array}{l}\text { Knowledge } \\
\text { of students }\end{array}$} & \multirow{2}{*}{$\begin{array}{l}\text { Number of } \\
\text { responses }\end{array}$} & \multicolumn{3}{|c|}{$\begin{array}{l}\text { Students from the } \\
\text { control group }\end{array}$} & \multicolumn{3}{|c|}{$\begin{array}{l}\text { Students from the } \\
\text { experimental groups }\end{array}$} \\
\hline & & $\begin{array}{l}\text { Number } \\
\text { of } \\
\text { young } \\
\text { men's } \\
\text { respons } \\
\text { es (\%) }\end{array}$ & $\begin{array}{l}\begin{array}{l}\text { Number } \\
\text { of } \\
\text { girls' }\end{array} \\
\text { respons } \\
\text { es } \\
\text { (\%) }\end{array}$ & $\begin{array}{l}\text { Total } \\
\text { number } \\
\text { respons } \\
\text { es } \\
\text { (\%) }\end{array}$ & $\begin{array}{l}\text { Number } \\
\text { of } \\
\text { young } \\
\text { men's } \\
\text { response } \\
\text { s (\%) }\end{array}$ & $\begin{array}{l}\text { Number } \\
\text { of } \\
\text { girls' } \\
\text { respons } \\
\text { es } \\
\text { (\%) }\end{array}$ & $\begin{array}{l}\text { Total } \\
\text { number } \\
\text { respons } \\
\text { es } \\
\text { (\%) }\end{array}$ \\
\hline \multirow{2}{*}{$\begin{array}{l}\text { the } \\
\text { terminology } \\
\text { of media / } \\
\text { media } \\
\text { culture }\end{array}$} & $\begin{array}{l}\text { the number } \\
\text { of correct } \\
\text { answers }\end{array}$ & 55,9 & 74,2 & 68,1 & 97,14 & 97,42 & 97,33 \\
\hline & $\begin{array}{l}\text { number of } \\
\text { incorrect } \\
\text { answers }\end{array}$ & 45,1 & 25,8 & 31,9 & 2,86 & 2,58 & 2,67 \\
\hline \multirow{2}{*}{$\begin{array}{l}\text { the history } \\
\text { media / } \\
\text { media } \\
\text { culture }\end{array}$} & $\begin{array}{l}\text { the number } \\
\text { of correct } \\
\text { answers }\end{array}$ & 32,6 & 38,3 & 36,7 & 83,57 & 78,39 & $\mathbf{8 0 , 0 0}$ \\
\hline & $\begin{array}{l}\text { number of } \\
\text { incorrect } \\
\text { answers }\end{array}$ & 67,4 & 61,7 & 63,3 & 16,43 & 21,61 & 20,00 \\
\hline \multirow{2}{*}{$\begin{array}{l}\text { the theory } \\
\text { media / } \\
\text { media } \\
\text { culture }\end{array}$} & $\begin{array}{l}\text { the number } \\
\text { of correct } \\
\text { answers }\end{array}$ & 37,8 & 56,5 & 50,6 & 83,57 & 86,77 & 85,78 \\
\hline & $\begin{array}{l}\text { number of } \\
\text { incorrect } \\
\text { answers }\end{array}$ & 62,2 & 43,5 & 49,4 & 16,43 & 13,23 & 14,22 \\
\hline \multirow{2}{*}{$\begin{array}{l}\text { the } \\
\text { terminology, } \\
\text { history and } \\
\text { media theory } \\
\text { / } \\
\text { media } \\
\text { culture } \\
\text { (as a whole) } \\
\end{array}$} & $\begin{array}{l}\text { number of } \\
\text { correct } \\
\text { answers }\end{array}$ & 42,1 & 56,3 & 49,2 & 88,10 & 84,19 & 87,70 \\
\hline & $\begin{array}{l}\text { number of } \\
\text { incorrect } \\
\text { answers }\end{array}$ & 57,9 & 43,7 & 50,8 & 11,90 & 15,81 & 12,30 \\
\hline
\end{tabular}

Further, it seemed to us important to analyze the combination of the levels of motivation and information indicators of media competence of students' audience in the control and experimental groups (see Table 10). 
Table 10: The combination of the identified levels of motivation and information indicators of media competence of students' audience in the control and experimental groups

\begin{tabular}{|c|c|c|c|c|c|c|c|}
\hline \multirow[t]{2}{*}{ № } & \multirow{2}{*}{$\begin{array}{l}\text { Combinatio } \\
\text { n of levels of } \\
\text { motivation } \\
\text { and } \\
\text { information } \\
\text { indicators }\end{array}$} & \multicolumn{3}{|c|}{ Students from the control group: } & \multicolumn{3}{|c|}{$\begin{array}{l}\text { Students from the } \\
\text { experimental } \\
\text { groups: }\end{array}$} \\
\hline & & 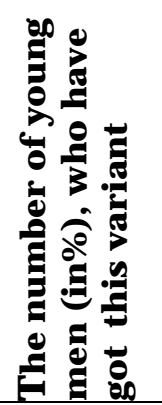 & 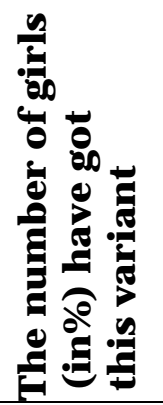 & 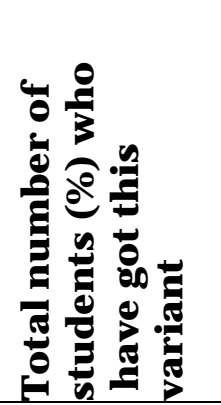 & 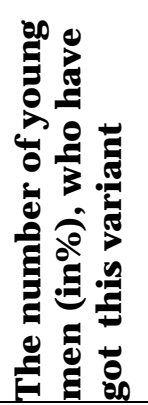 & 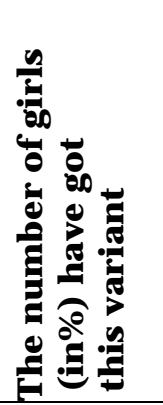 & 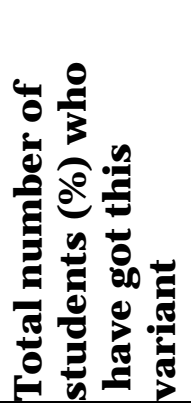 \\
\hline 1 & $\begin{array}{l}\text { The } \\
\text { combination } \\
\text { of } \\
\text { low levels }\end{array}$ & 57,14 & 19,35 & 31,11 & 0,00 & 0,00 & $\mathbf{0 , 0 0}$ \\
\hline 2 & $\begin{array}{l}\text { The } \\
\text { combination } \\
\text { of average } \\
\text { levels }\end{array}$ & 14,29 & 19,35 & 17,78 & 0,00 & 3,22 & 2,22 \\
\hline 3 & $\begin{array}{l}\text { The } \\
\text { combination } \\
\text { of } \\
\text { high levels }\end{array}$ & 0,00 & 6,45 & 4,44 & 14,28 & 29,03 & 25,09 \\
\hline 4 & $\begin{array}{l}\text { mismatching } \\
\text { levels }\end{array}$ & 28,57 & 54,84 & 46,67 & 85,72 & 67,75 & 72,69 \\
\hline
\end{tabular}

Analysis of the data in Table 10 shows that the discrepancy between the levels of motivation and information indicators of media competence of the students' audience - a common phenomenon, concerning approximately $50 \%$ - $70 \%$ of respondents.

Thus, some students may not have a special awareness of the media / media culture, but the same students may have a more or less diverse motives contacts with media texts, and vice versa.

Our study also showed that a strong correlation between the frequency of students' contacts with media and students' motivational and / or indicators of development of information media competence does not exist. The vast majority of respondents (73.33 \% - in the control group and $66.67 \%$ - in the pilot) found, for example, a high level of contact indicator of media competence in relation to the TV, but it only $4.44 \%$ of the students in the control group and $25.09 \%$ - in the experimental group showed a pronounced combination of high levels of motivation and information indicators of media competence.

But we can clearly see a correlation between a high level of development of students' information and media competence in the experimental group. So just $13.33 \%$ of the students in the control group found a high level of development of information media competence development indicators, while in the students' experimental group (which was read during the year training course on the basics of media culture and media education), the figure was $95.55 \%$.

Analysis of the data in Table 11 shows that the students in the control group is dominated by the low level of evaluation indicator of media competence ("ignorance", that is, ignorance of the language of media, instability confused judgment, susceptibility to external influence, the lack of interpretation of the position of the characters and authors of media texts, the ability to retell plot works, the ability for the simple analysis of media text, but based on the low levels of "information", "motivational" and "perceptual" indicators). Such students in the control group was $71 \%$ (with no significant gender difference). The students of the experimental group detected 3.5 times less often (20 \%) a low level of evaluation indicator of media competence. 
Table 11: The classification of the identified levels of evaluation indicator of students' media competence in the control and experimental groups

\begin{tabular}{|c|c|c|c|c|c|c|c|}
\hline \multirow[t]{2}{*}{ № } & \multirow{2}{*}{$\begin{array}{l}\text { Levels of } \\
\text { evaluation } \\
\text { indicator: }\end{array}$} & \multicolumn{3}{|c|}{$\begin{array}{l}\text { Students from the control } \\
\text { group: }\end{array}$} & \multicolumn{3}{|c|}{$\begin{array}{l}\text { Students from the experimental } \\
\text { groups: }\end{array}$} \\
\hline & & 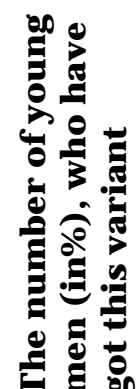 & 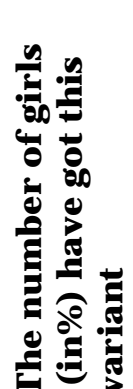 & 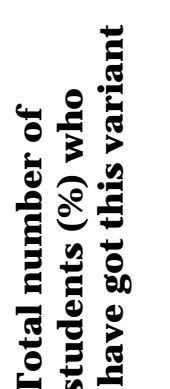 & 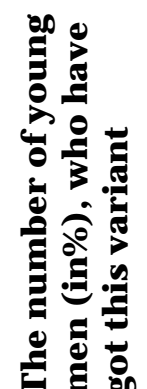 & 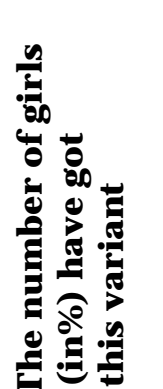 & 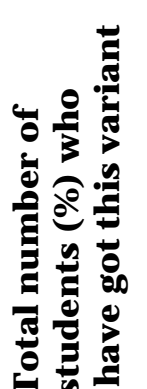 \\
\hline 1 & High level & 7,14 & 3,22 & 4,44 & 7,14 & 35,48 & 26,67 \\
\hline 2 & Average level & 21,43 & 29,03 & 26,67 & 42,86 & 58,07 & 53,33 \\
\hline 3 & Low level & 71,43 & 67,74 & 71,43 & 50,00 & 6,45 & 20,00 \\
\hline
\end{tabular}

I can give a lot of examples here, but they all boil down to the monotonous and short or long retelling the plot of a media text. Of course, I can find in one way or another retelling of the plot the elements of reliance on the media insight at identification with the character, but it is, in fact, only the elements, hints that ultimately have little effect on the overall low level of analytical skills of the respondents.

The average level of evaluation indicator of students' media competence (the ability to characterize the acts and psychological character of a media text on the basis of fragmentary knowledge, the ability to explain the logic of the sequence of events in the story, the ability to talk about the individual components of the media image, the lack of interpretation of the author's position (or a primitive interpretation of it), and simple analysis media text, based on the average levels of "information", "motivational" and "perceptual" indexes of media competence), proved to be peculiar to about $26 \%$ of the students in the control group (also without any significant gender differences).

The students of the experimental group have more high (53\%) of the average level of evaluation indicator of media competence.

The high level of evaluation indicator of media competence (analysis skills based on the capacity for media insight, close to the "complex identification", capacity for analysis and synthesis of spatial-temporal form of media text, understanding, interpretation and evaluation of the author's concept in the context of product structure (with the expressions a reasoned agreements or disagreements with the position of the media text creators), the social significance of media text (eg its relevance), the ability to relate the emotional experience with conceptual judgment, this judgment to move to other genres and types of media culture, media text to associate with the experience and expertise of other humans, etc.; analysis skills based on high levels of "information", "motivational" and "perceptual" indexes of media competence) found only $4 \%$ of the students in the control group. But the students of the experimental group have a high level of evaluative indicator of media competence is six times higher (26\%, with the apparent significant gender dominant of female respondents).

This is a significant difference in the levels of performance indicators between students control and experimental groups emerged, despite the fact that, as mentioned earlier, many of the students in the control group had a fairly high contact performance levels of media competence (eg, $73 \%$ of students in the control group have found high levels of television viewing).

Thus, analysis of the data in Table 11 once again convince us that high frequency of contacts with the media in itself does not lead to a high level of ability to the full perception / analysis skills. But on the level of evaluation indicator of media competence of students significantly reflected their levels of information and motivational indicators of media competence.

In contrast, the comparative analysis of the data tables show that low levels of motivation (57.78 \%), information (37.78 \%) and evaluation (71.43\%) indicators of media competence of 
students in the control group it is correlated with one other. However, as clearly relate to the same group of high levels of motivation (11.11\%), information (13.13\%) and evaluation (4.14 \%) indices.

Thus, low estimates in the development of media competence of students in most cases is associated with similar levels of their motivational and informational indicators and vice versa ...

If we turn to the comparative analysis of a number of tables in the experimental group, we can see that the presence of a high level of information index of media competence (95\%) does not guarantee for students the same high level evaluation indicator of media competence. In any case, only $26.67 \%$ of the students of the experimental group were able to confirm the high level of media competence of evaluation indicators, while half of the students (53.33\%) found the average evaluation indicators. These data lead us to believe that in itself the awareness in the field of terminology, theory and history of media / media culture does not automatically improve the analytical skills for evaluation of media texts. This is also indicated by the numbers low estimates in the development of media competence.

Most correlation is observed in the experimental group the levels of motivation and evaluation indicators of media competence (31 \% of students with low motivation index corresponds with $20 \%$ of students with low evaluation indicator, the ratio of the average level is $44 \%$ and $53 \%$, and high - $21 \%$ and $26 \%$ ).

Since the operating rate (high level: practical skills of independent creation of media texts of different types and genres; the average level: practical skills of creating media texts with the help of counseling teachers / professionals; low level: the lack of practical skills of creating media texts or unwillingness of their creation) - the part of creative component of the media competence, I did not analyze it separately. I note only that our monitoring the implementation of creative works by students of various types have shown that the level of operating performance correlates well with the level of creative figure. Students who do not have practical skills in the field of media are not able to create media texts. Although, of course, on their own practical skills do not guarantee a high level of creative index of media competence. This lack of direct dependence of practical skills and creative results is well known among professionals in the world media, when several dozen annual media faculty's graduates don't have the possibilities for creating the high level media production...

Table 12: The classification of the identified levels of creative indicator of students' media competence in the control and experimental groups

\begin{tabular}{|c|c|c|c|c|c|c|c|}
\hline \multirow[t]{2}{*}{ № } & \multirow{2}{*}{$\begin{array}{l}\text { Levels } \\
\text { of } \\
\text { creative } \\
\text { indicat } \\
\text { or: }\end{array}$} & \multicolumn{3}{|c|}{ Students from the control group: } & \multicolumn{3}{|c|}{$\begin{array}{l}\text { Students from the experimental } \\
\text { groups: }\end{array}$} \\
\hline & & 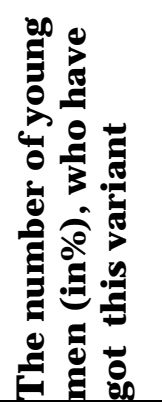 & 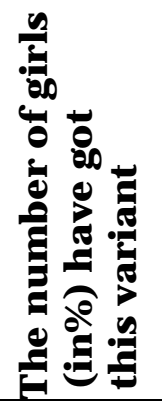 & 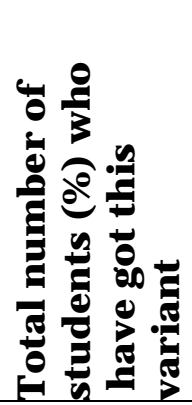 & 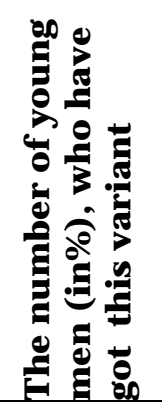 & 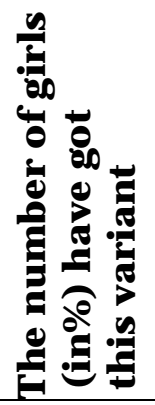 & 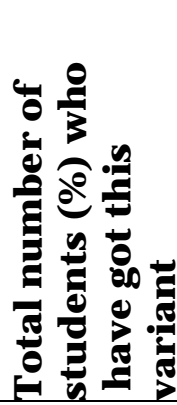 \\
\hline 1 & $\begin{array}{l}\text { High } \\
\text { level }\end{array}$ & 14,28 & 22,58 & 20,00 & 7,14 & 74,20 & 53,33 \\
\hline 2 & $\begin{array}{l}\text { Averag } \\
\text { e level }\end{array}$ & 14,28 & 19,36 & 17,78 & 71,43 & 19,35 & 35,55 \\
\hline 3 & $\begin{array}{l}\text { Low } \\
\text { level }\end{array}$ & 71,43 & 58,06 & 62,22 & 21,43 & 6,45 & 11,11 \\
\hline
\end{tabular}

Analysis of the data in Table 12 shows that between the levels of operating abilities and creative development of media competence there is a clear relationship. Learning for the creation of media texts of different types and genres, students in the experimental group twice exceeded the control group of students (high and medium levels of creative index of media competence). At the same time $53 \%$ of the students of the experimental group found a high level of creative index of 
media competence, that is a distinct level of creativity in various activities (perceptual, games, art, etc..), related to the media. In the control group, the percentage was only $20 \%$. The number of girls with high creativity was higher than the number of boys. Conversely, the number of young men with low indicator of creative media competence was significantly higher than that of girls.

Analysis of the data in Table 13 show that the discrepancy Between the levels of creative and evaluation indicators of media competence of the student audience is found in almost half of the respondents. This occurs more often an option when the level of development of creative media competence indicator is higher than the estimated level (this is particularly noticeable in the experimental group, which had the opportunity to develop their operational and creative abilities on media in the process of studying the curriculum).

But clearly traced common combination of low levels of creative and evaluation indicators of media competence of students in the control group (64\% of boys and $48 \%$ girls).

Table 13: The combination of the identified levels of creative and evaluation indicators of media competence of students' audience in the control and experimental groups

\begin{tabular}{|c|c|c|c|c|c|c|c|}
\hline & \multirow{2}{*}{$\begin{array}{l}\text { Combinati } \\
\text { on of } \\
\text { levels of } \\
\text { creative } \\
\text { and } \\
\text { evaluation } \\
\text { indicators }\end{array}$} & \multicolumn{3}{|c|}{ Students from the control group: } & \multicolumn{3}{|c|}{$\begin{array}{l}\text { Students from the experimental } \\
\text { groups: }\end{array}$} \\
\hline & & 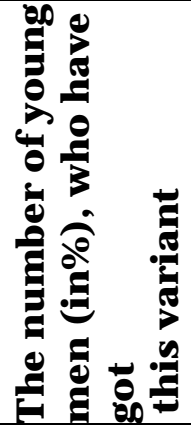 & 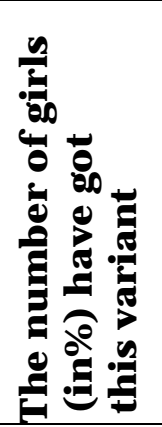 & 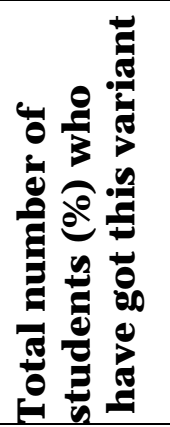 & 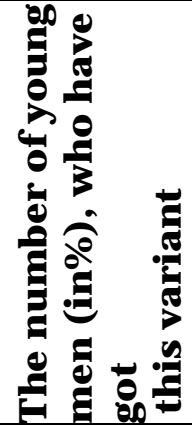 & 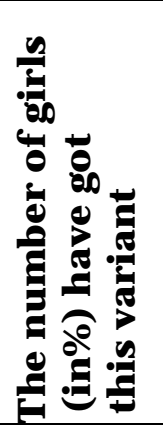 & 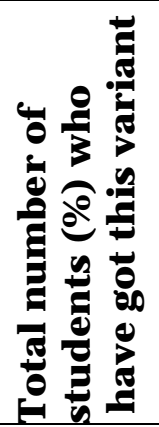 \\
\hline 1 & $\begin{array}{l}\text { The } \\
\text { combinati } \\
\text { on of } \\
\text { low levels }\end{array}$ & 64,29 & 41,94 & 48,89 & 14,29 & 6,45 & $\mathbf{8 , 8 9}$ \\
\hline 2 & $\begin{array}{l}\text { The } \\
\text { combinati } \\
\text { on of } \\
\text { average } \\
\text { levels }\end{array}$ & 7,14 & 0,00 & 2,22 & 35,71 & 16,13 & 22,22 \\
\hline 3 & $\begin{array}{l}\text { The } \\
\text { combinati } \\
\text { on of } \\
\text { high } \\
\text { levels }\end{array}$ & 7,14 & 3,21 & 4,44 & 7,14 & 32,26 & 24,44 \\
\hline 4 & $\begin{array}{l}\text { Mismatch } \\
\text { ing levels }\end{array}$ & 21,43 & 54,84 & $\overline{44,44}$ & 42,86 & 45,16 & $\mathbf{4 4 , 4 4}$ \\
\hline
\end{tabular}

Gender differences are evident, above all, that the coincidence of low levels of creative and evaluation indicators of media competence was more common among young men in the control group, while in the experimental group, a greater number of matches to high levels of the above indicators were observed in girls. The limited sample of respondents does not allow us to make farreaching conclusions, but will not be superfluous to note that women in general are more likely than boys attended classes, so get more operating skills on the basis of which were better able to develop their creative abilities on media material.

After analyzing the data tables 1-13, I have made the table of 14 for the classification level of the complex index of media competence of students of the control and experimental groups. 
At the same time, I agreed to assume that the students, with the highest level of comprehensive media competence I carried those who in the course of the study showed a high rate of three or four major indicators except for the contact. In the experimental group of students were 12 people (26.67\%) of them - 11 girls. In the control group - only two people, both girls (4.44 \%).

Table 14: The classification of the identified levels of complex indicator of students' media competence in the control and experimental groups

\begin{tabular}{|c|c|c|c|c|c|c|c|}
\hline \multirow[t]{2}{*}{ № } & \multirow{2}{*}{$\begin{array}{l}\text { Levels of } \\
\text { complex } \\
\text { indicator } \\
\text { of media } \\
\text { compete } \\
\text { nce }\end{array}$} & \multicolumn{3}{|c|}{ Students from the control group: } & \multicolumn{3}{|c|}{$\begin{array}{l}\text { Students from the experimental } \\
\text { groups: }\end{array}$} \\
\hline & & 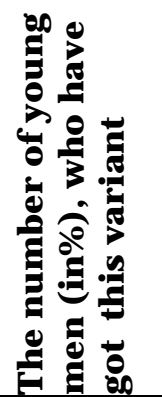 & 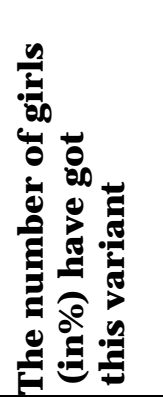 & 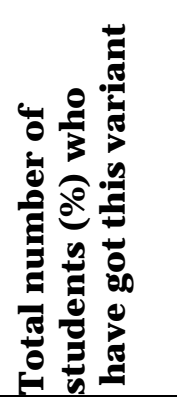 & 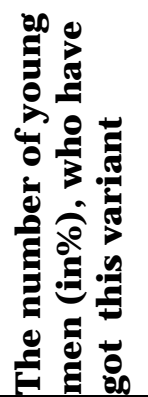 & 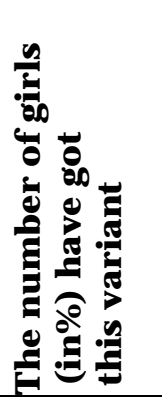 & 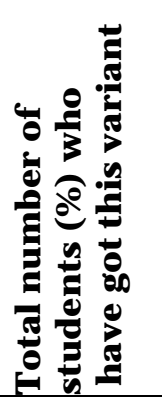 \\
\hline 1 & $\begin{array}{l}\text { High } \\
\text { level }\end{array}$ & 0,00 & 6,45 & 4,44 & 7,14 & 35,48 & 26,67 \\
\hline 2 & $\begin{array}{l}\text { Average } \\
\text { level }\end{array}$ & 21,43 & 12,90 & 15,55 & 35,71 & 58,06 & 51,11 \\
\hline 3 & $\begin{array}{l}\text { Low } \\
\text { level }\end{array}$ & 78,57 & 80,64 & $\mathbf{8 0 , 0 0}$ & 57,14 & 6,45 & 22,22 \\
\hline
\end{tabular}

For students with an average level of development of a media competence I assigned students who in the course of the study there was not a single low-level indicator on the three most important positions (level of information, evaluation and creative abilities). In the experimental group of students this level was about half (51.11\%: 35.71\% boys and 58.06\% girls). In the control group, this level was detected only in $15 \%$ of students.

For students who have a low level of development of a media competence, I included those who in the course of the study it was found by one or more manifestations of the low level of the index in the three most important positions above. In the control group, those turned four times larger than the experimental value. Moreover, if the control underperformed the boys and girls are quite comparable, it is dominated by young men in the experimental low-media competence: they are 9 times more than women (which, in my opinion, was due to the narrow quantitative sample of respondents).

In general, the data in Table 14 demonstrate the effectiveness on our media literacy education pilot training course, the effectiveness of our methods.

\section{The classification of the identified levels of the various indicators of media competence at students of experimental and control groups}

The lack of many sociological studies, in our opinion, is that skillfully results in terms of mass surveys, the authors do not always try to analyze and compare the knowledge / skills of a particular person, which in some areas can be a very high level, and in others - medium or low...

That's why the main feature of our ascertaining experiment was that in addition to the traditional study and analysis of the "anonymous" preferences and knowledge over / under on the number of respondents for the audience, an attempt was made case study: the study and analysis of the levels of development of specific media competence of students / individuals. From each group of respondents (high, medium and low levels of indicators of media competence), I selected typical representatives, answers, creativity and practical work Were analyzed to identify relationships and dependencies of motivational levels, contact, information, analytical, creative (and partially operational) indicators of media competence in a particular individual. 
First there the tables of 15 and 16 give an overview of the classification levels of the various indicators of media competence at students of experimental and control groups.

Table 15: The classification of the identified levels of the various indicators of media competence of students of the experimental group

\begin{tabular}{|c|c|c|c|c|c|c|}
\hline \multirow[t]{2}{*}{ № } & \multirow[b]{2}{*}{ Students } & \multicolumn{5}{|c|}{ Indicators of media competence } \\
\hline & & $\begin{array}{l}\text { Levels of } \\
\text { motivation } \\
\text { indicator }\end{array}$ & $\begin{array}{l}\text { Levels of } \\
\text { contact } \\
\text { indicator }\end{array}$ & $\begin{array}{l}\text { Levels of } \\
\text { information } \\
\text { indicator }\end{array}$ & $\begin{array}{l}\text { Levels of } \\
\text { evaluation } \\
\text { indicator }\end{array}$ & $\begin{array}{l}\text { Levels of } \\
\text { creative } \\
\text { indicator }\end{array}$ \\
\hline 1 & Alexandra A. & Average & Average & High & High & Average \\
\hline 2 & Anna D. & Average & Average & High & Average & Average \\
\hline 3 & Anna K. & Low & Average & High & Average & High \\
\hline 4 & Anna M. & High & Average & High & Average & Average \\
\hline 5 & Anna P. & Low & Average & High & Average & High \\
\hline 6 & Anna U. & Average & Average & High & High & High \\
\hline 7 & Ekaterina I. & Average & Average & High & Average & High \\
\hline 8 & Elena V. & High & Average & High & High & High \\
\hline 9 & Elena G. & High & Average & High & High & High \\
\hline 10 & Elena E. & High & Average & High & Average & High \\
\hline 11 & Elena C. & Average & Average & High & Average & Average \\
\hline 12 & Inna V. & Low & Average & High & High & High \\
\hline 13 & Inna L. & Average & Average & High & High & High \\
\hline 14 & Irina K. & Average & Average & Average & Average & High \\
\hline 15 & Irina C. & Average & Average & High & Average & High \\
\hline 16 & Irina M. & High & Average & High & Low & Low \\
\hline 17 & Irina $\mathrm{N}$. & Average & Low & High & Average & High \\
\hline 18 & Irina S. & High & Average & High & Average & Average \\
\hline 19 & Karina I. & Average & Low & High & Average & High \\
\hline 20 & Karina U. & Low & Average & High & High & High \\
\hline 21 & Lubov A. & Average & Average & High & Average & Average \\
\hline 22 & Maria B. & High & Average & High & High & High \\
\hline 23 & Maria G. & Low & Average & High & High & High \\
\hline 24 & Maria K. & High & Average & High & High & High \\
\hline 25 & Natalia L. & High & Average & High & High & High \\
\hline 26 & Oksana M. & Average & Average & High & Average & High \\
\hline 27 & Olga G. & Average & Average & High & Average & High \\
\hline 28 & Tatiana B. & Low & Average & High & Average & High \\
\hline 29 & Tatiana E. & Low & Average & High & Average & High \\
\hline 30 & Tatiana P. & Average & Average & High & Average & High \\
\hline 31 & Tatiana T. & Average & Average & High & Low & Low \\
\hline 32 & Alexander D. & Low & Average & Average & Low & Low \\
\hline 33 & Alexei E. & Average & Low & High & Average & Average \\
\hline 34 & Alexei H. & Low & Low & High & Low & Average \\
\hline 35 & Anadrei $\mathrm{O}$. & Average & Average & High & Low & Average \\
\hline 36 & Valery V. & Low & Average & High & Average & Average \\
\hline 37 & Valery K. & Average & Average & High & Low & Average \\
\hline 38 & Vassily A. & Average & Average & High & Average & Average \\
\hline 39 & Vayacheslav S. & Low & High & High & Low & Average \\
\hline 40 & Dmitry I. & High & Average & High & Average & Average \\
\hline 41 & Eugeny K. & Average & Average & High & High & High \\
\hline 42 & Igor P. & High & Low & High & Average & Average \\
\hline 43 & Roman S. & Low & Average & High & Average & Low \\
\hline 44 & Segei D. & Low & Average & High & Low & Average \\
\hline 45 & Sergei S. & Low & High & High & Low & Low \\
\hline
\end{tabular}


Table 16: The classification of the identified levels of the various indicators of media competence of students of the control group

\begin{tabular}{|c|c|c|c|c|c|c|}
\hline \multirow[t]{2}{*}{ No } & \multirow[t]{2}{*}{ Students } & \multicolumn{5}{|c|}{ Indicators of media competence } \\
\hline & & $\begin{array}{l}\text { Levels of } \\
\text { motivation } \\
\text { indicator }\end{array}$ & $\begin{array}{l}\text { Levels of } \\
\text { contact } \\
\text { indicator }\end{array}$ & $\begin{array}{l}\text { Levels of } \\
\text { information } \\
\text { indicator }\end{array}$ & $\begin{array}{l}\text { Levels of } \\
\text { evaluation } \\
\text { indicator }\end{array}$ & $\begin{array}{l}\text { Levels of } \\
\text { creative } \\
\text { indicator }\end{array}$ \\
\hline 1 & Alexandra $\mathrm{P}$. & Average & Average & High & Average & Low \\
\hline 2 & Anna K. & Average & Average & Average & Average & Low \\
\hline 3 & Anna O. & Low & Average & Average & Low & Average \\
\hline 4 & Valeria R. & Low & Average & Average & Average & High \\
\hline 5 & Victoria B. & High & Average & Average & Low & Low \\
\hline 6 & Victoria E. & Low & Average & Average & Low & Average \\
\hline 7 & Ekaterina D. & Average & Average & Average & Average & High \\
\hline 8 & Ekaterina K. & High & Average & High & High & High \\
\hline 9 & Elena A. & High & Average & High & Average & High \\
\hline 10 & Elena B. & Low & Average & Low & Low & Low \\
\hline 11 & Elena V. & Average & Low & Low & Low & Low \\
\hline 12 & Elena $\mathrm{K}$. & Average & Average & Average & Average & Low \\
\hline 13 & Elena L. & Low & Average & Average & Low & Low \\
\hline 14 & Elena C. & Average & Average & High & Average & Low \\
\hline 15 & Irina C. & Low & Average & Low & Low & Low \\
\hline 16 & Irina S. & High & Average & Average & Low & Average \\
\hline 17 & Lubov C. & Low & Average & Low & Low & Low \\
\hline 18 & Marina B. & Average & Average & High & Average & High \\
\hline 19 & Natalia E. & Average & Low & Low & Low & Low \\
\hline 20 & Natalia R. & Low & Low & Low & Low & Low \\
\hline 21 & Oksana L. & Low & Average & Average & Low & Average \\
\hline 22 & Oksana S. & Average & Average & Average & Average & Low \\
\hline 23 & Olga V. & Low & Average & Low & Low & Low \\
\hline 24 & Olga I. & Low & Average & Average & Low & Average \\
\hline 25 & Olga L. & Low & Average & Average & Low & Low \\
\hline 26 & Svetlana K. & Low & Average & Average & Low & Low \\
\hline 27 & Svetlana S. & High & Average & Average & Average & High \\
\hline 28 & Tatiana T. & Average & Average & Average & Low & Low \\
\hline 29 & Juliana S. & Low & Average & Low & Low & Low \\
\hline 30 & Julia Z. & Low & Average & Average & Low & Average \\
\hline 31 & Julia S. & Average & Low & Average & Low & High \\
\hline 32 & Alexander B. & Low & Average & Low & Low & Low \\
\hline 33 & Alexei B. & Low & Average & High & Average & High \\
\hline 34 & Alexei K. & Average & Low & Low & Low & Low \\
\hline 35 & Alexei P. & Average & Average & Average & Average & Average \\
\hline 36 & Andrei G. & Low & High & Average & Average & Low \\
\hline 37 & Andrei S. & Average & Average & Average & High & High \\
\hline 38 & Anton A. & Low & Average & Low & Low & Low \\
\hline 39 & Vladislav H. & Low & Averace & Low & Low & Low \\
\hline 40 & Dmitry K. & Low & Average & Low & Low & Low \\
\hline 41 & Kirill G. & Low & Low & Low & Low & Low \\
\hline 42 & Nikolai G. & Low & Average & Average & Low & Low \\
\hline 43 & OlegP. & Low & Average & Low & Low & Average \\
\hline 44 & Pavel G. & Low & Average & Low & Low & Low \\
\hline 45 & Sergei S. & Low & Average & Low & Low & Low \\
\hline
\end{tabular}


Based on the data in Tables 15 and 16, I have analyzed the students' responses, typical symptoms of various levels (high, Average and low) the development of media competence.

Group A - the high level indicator of media competence of the student.

Here you can select a student Maria K., who has only one indicator of the average level contact. All the rest are high. In fact, Maria K. has a diverse range of media motivations, she gained a solid knowledge base in the field of terminology, theory and history of media literacy education. But most importantly, she is a creative person with a high level of perception and analytical thinking in relation to the media texts. She did all types of creative works during a year-long study of media literacy education courses, as well as the reviews, remarks in the discussion of media texts, etc.

Eugeny K. and Inna L. showed at the end of a year-long training and a similar levels of media competence.

The high level indicator of media competence of the students: $26 \%$ in the experimental group, and only $4 \%$ in the control group.

Group B - the average indicator of media competence of the student.

Here, as a typical student can distinguish Irina $\mathrm{K}$., in which there is only one indicator of the high level - creative. All the others - average. This diligent student does not have a strong abilities for the study of media culture. She achieves a average level of knowledge, including media literacy education. However, implementation of creative works opened her hidden potential research innovative solutions (for example, in the collage on media topic). Other typical members of this group: Anna D. (she has many averages levels of media competence, but because of her natural memory, she showed a high level of knowledge of terminology, theory and history of media culture) and Ekaterina D.

The average level indicator of media competence of the students: 51\% in the experimental group, and only $15 \%$ in the control group.

Group C - the low level of the indicator of media competence of the student.

It is not difficult to identify a typical student: Kirill G., Pavel G., Sergei S. Some of them have the average levels of contacts with media, but all other indicators of the level of media competence consistently low. Motivation of their media contacts limited attraction to entertainment. They are not at all interested in the theory and history of media / media culture. Perceptual and analytical skills in relation to media texts have absolutely undeveloped. Creativity also occur ... As a rule, they are looking the possibilities to skip classes. They are not interested at all of their future profession. Their target - receiving a state diploma in higher education. The real motives of their studies (defined again, rather their parents) are generally reduced to three parent "so as not to" (for young men, "so as not to be in the army", "not to hang around the streets and doorways," "not to fell into bad company "; for the girls," that was not worse than the others "," not to dally " "not to remain without a diploma").

The low level indicator of media competence of the students: $22 \%$ in the experimental group, and only $80 \%$ in the control group.

\section{Analy sis of the performance of students of the creative tasks of content analy sis of media texts}

To further clarify of students' media competence, and the results of students performing creative tasks on content analysis of media texts I used the media educational methodology of A. Silverblatt (Silverblatt, 2001, pp. 62-64). The experiment involved 38 students (31 girl and 7 boys, aged 20-21 years) of Anton Chekhov Taganrog Institute. Each of them chose a content analysis of three of their favorite media texts of different types and genres. 114 students analyzed media texts for a total. Students analyzed the main media characters, their gender, age, race, level of education, type of work / study, marital status, number of children, appearance, personality traits, the role and influence of these characters in the media text.

These results were eventually brought us to the table 17. 
Table 17: Results of the students creative tasks on content analysis of media texts

\begin{tabular}{|c|c|c|c|c|}
\hline & Categories & $\begin{array}{l}\text { Selection of } \\
\text { female students } \\
\text { ( \%) }\end{array}$ & $\begin{array}{l}\text { Selection of } \\
\text { male students( } \\
\text { \%) }\end{array}$ & $\begin{array}{l}\text { Selection of } \\
\text { all students ( \%) }\end{array}$ \\
\hline 1. & \multicolumn{4}{|l|}{ Types of media texts } \\
\hline 1.1. & Films, serials & 48,39 & 85,71 & 55,26 \\
\hline 1.2. & TV products & 41,93 & 28,57 & 39,47 \\
\hline 1.3. & Presse, print & 6,45 & 0,00 & 5,26 \\
\hline 1.4. & Video games & 3,22 & 0,00 & 2,63 \\
\hline 1.5. & Other media texts & 0,00 & 0,00 & 0,00 \\
\hline 2. & \multicolumn{4}{|l|}{ Genres of media texts } \\
\hline 2.1. & Comedy & 25,81 & 28,57 & 26,31 \\
\hline 2.2 . & Melodrama & 29,03 & 0,00 & 23,68 \\
\hline 2.3. & Reality show & 12,90 & 0,00 & 10,53 \\
\hline 2.4 . & Talk show & 9,68 & 14,28 & 10,53 \\
\hline 2.5. & Fantasy & 6,45 & 28,57 & 10,53 \\
\hline 2.6. & Entertainment show & 6,45 & 0,00 & 5,26 \\
\hline 2.7. & Drama & 6,45 & 0,00 & 5,26 \\
\hline 2.8. & Detective story & 6,45 & 0,00 & 5,26 \\
\hline 2.9 . & Criminal drama & 0,00 & 28,57 & 5,26 \\
\hline 2.10 . & Other genres & 6,45 & 14,28 & 7,89 \\
\hline 3. & \multicolumn{4}{|c|}{ Gender of media text character } \\
\hline 3.1. & male & 58,06 & 85,71 & 63,16 \\
\hline 3.2. & female & 41,93 & 14,28 & 36,84 \\
\hline 4. & \multicolumn{4}{|c|}{ Age of media text character } \\
\hline 4.1. & $0-5$ & 3,22 & 0,00 & 2,63 \\
\hline 4.2. & $6-12$ & 3,22 & 0,00 & 2,63 \\
\hline 4.3. & $13-18$ & 3,22 & 14,28 & 5,26 \\
\hline 4.4. & $19-25$ & 32,26 & 42,86 & 34,21 \\
\hline 4.5. & $26-35$ & 45,16 & 28,57 & 42,10 \\
\hline 4.6. & $36-50$ & 9,68 & 14,28 & 10,53 \\
\hline 4.7. & $50-65$ & 6,45 & 14,28 & 7,89 \\
\hline 4.8. & over 65 & 0,00 & 0,00 & 0,00 \\
\hline 5. & \multicolumn{4}{|c|}{ Race of media text character } \\
\hline 5.1. & White & 83,87 & 85,71 & 84,21 \\
\hline 5.2. & Color & 6,45 & 0,00 & 5,26 \\
\hline 5.3. & Blacks & 0,00 & 14,28 & 2,63 \\
\hline 5.4. & Asian & 3,22 & 0,00 & 2,63 \\
\hline 5.5. & Latino & 3,22 & 0,00 & 2,63 \\
\hline 5.6. & Other & 6,45 & 0,00 & 5,26 \\
\hline 6. & \multicolumn{4}{|c|}{ Level of education of media text character } \\
\hline 6.1. & University & 64,52 & 57,14 & 63,16 \\
\hline 6.2 . & High school & 22,58 & 28,57 & 23,68 \\
\hline 6.3. & Elementary school & 3,22 & 14,28 & 5,26 \\
\hline 6.4. & другое & 9,68 & 0,00 & 7,89 \\
\hline 7. & \multicolumn{4}{|c|}{ Type of job/education of media text character } \\
\hline 7.1. & skilled worker & 67,74 & 57,14 & 65,79 \\
\hline 7.2 . & Unemployed & 9,68 & 14,28 & 10,53 \\
\hline 7.3. & Students & 6,45 & 28,57 & 10,53 \\
\hline 7.4 . & worker of low qualification & 9,68 & 14,28 & 10,53 \\
\hline 7.5. & $\begin{array}{l}\text { an employee occupying } \\
\text { high position }\end{array}$ & 3,22 & 0,00 & 2,63 \\
\hline 7.6. & Others & 6,45 & 14,28 & 7,89 \\
\hline 8. & \multicolumn{4}{|c|}{ Marital status of media text character } \\
\hline 8.1. & Bachelor & 51,61 & 71,42 & 55,26 \\
\hline 8.2 . & married & 38,71 & 28,57 & 36,84 \\
\hline 8.3. & Divorced & 6,45 & 0,00 & 5,26 \\
\hline
\end{tabular}




\begin{tabular}{|c|c|c|c|c|}
\hline 8.4. & Civil marriage & 3,22 & 0,00 & 2,63 \\
\hline 8.5. & WidoIr/ Widow & 3,22 & 0,00 & 2,63 \\
\hline 8.6. & Other & 0,00 & 0,00 & 0,00 \\
\hline 9. & \multicolumn{4}{|c|}{ Number of children that media character has } \\
\hline 9.1. & 0 & 67,74 & 85,71 & 71,05 \\
\hline 9.2. & 1 & 25,81 & 14,28 & 23,68 \\
\hline 9.3. & 2 & 6,45 & 0,00 & 5,26 \\
\hline 9.4. & 3 and more & 3,22 & 0,00 & 2,63 \\
\hline 10. & \multicolumn{4}{|c|}{ Appearance of media text character } \\
\hline 10.1 & $\begin{array}{l}\text { Attractiveness for traditional } \\
\text { standards }\end{array}$ & 58,06 & 57,14 & 57,89 \\
\hline 10.2 & $\begin{array}{l}\text { Averaging for traditional } \\
\text { standards }\end{array}$ & 29,03 & 42,86 & 31,58 \\
\hline 10.3. & Charming / glamor & 9,68 & 0,00 & 7,89 \\
\hline 10.4 . & $\begin{array}{l}\text { Unpleasantness for traditional } \\
\text { standards }\end{array}$ & 6,45 & 14,28 & 7,89 \\
\hline 10.5 & Other & 3,22 & 0,00 & 2,63 \\
\hline 11. & \multicolumn{4}{|c|}{ Body style of media text character } \\
\hline 11.1. & average Iight/ figure & 41,93 & 42,86 & 42,10 \\
\hline 11.2. & harmony / leanness & 38,71 & 14,28 & 34,21 \\
\hline 11.3. & Athletic & 16,13 & 14,28 & 15,79 \\
\hline 11.4. & Iight above average & 0,00 & 28,57 & 5,26 \\
\hline 11.5. & fullness & 6,45 & 0,00 & 5,26 \\
\hline 11.6. & Other & 3,22 & 0,00 & 2,63 \\
\hline 12 & \multicolumn{4}{|l|}{ Character Traits } \\
\hline 12.1. & independence & 70,97 & 57,14 & 68,42 \\
\hline 12.2. & dependency & 3,22 & 0,00 & 2,63 \\
\hline 12.3. & intellectuality & 51,61 & 42,86 & 50,00 \\
\hline 12.4. & dullness & 3,22 & 0,00 & 2,63 \\
\hline 12.5. & straightforwardness & 41,93 & 57,14 & 36,84 \\
\hline 12.6. & cunning, resourcefulness & 9,68 & 14,28 & 10,78 \\
\hline 12.7. & Activity, ownership situation & 35,48 & 57,14 & 42,10 \\
\hline 12.8. & passivity & 3,22 & 0,00 & 2,63 \\
\hline 12.9. & wittiness & 35,48 & 28,57 & 34,21 \\
\hline 12.10 . & irony,sarcastic & 9,68 & 0,00 & 7,89 \\
\hline 12.11 & $\begin{array}{l}\text { the object of humor / } \\
\text { ridicule, irony by } \\
\text { other characters }\end{array}$ & 6,45 & 14,28 & 7,89 \\
\hline 12.12. & diligence & 35,48 & 14,28 & 31,58 \\
\hline 12.13. & carelessness & 12,90 & 0,00 & 10,53 \\
\hline 12.14. & Fidelity & 35,48 & 14,28 & 31,58 \\
\hline 12.15. & betrayal & 0,00 & 0,00 & 0,00 \\
\hline 12.16. & Optimism & 67,74 & 71,43 & 68,42 \\
\hline 12.17. & Pessimism & 0,00 & 0,00 & 0,00 \\
\hline 12.18. & truthfulness & 32,26 & 28,57 & 31,58 \\
\hline 12.19 . & lying & 0,00 & 0,00 & 0,00 \\
\hline 12.20 . & naivety & 9,68 & 0,00 & 7,89 \\
\hline 12.21. & cynicism & 0,00 & 0,00 & 0,00 \\
\hline 12.22 . & goodness & 35,48 & 14,28 & 31,58 \\
\hline 12.23. & Cruelty & 3,22 & 14,28 & 5,26 \\
\hline 12.24 . & PoIr, resoluteness & 16,13 & 28,57 & 18,42 \\
\hline 12.25. & Iakness, hesitancy & 6,45 & 14,28 & 7,89 \\
\hline 12.26. & courage & 16,13 & 28,57 & 18,42 \\
\hline 12.27. & cowardice & 0,00 & 0,00 & 0,00 \\
\hline 12.28 . & hard-working & 32,25 & 14,28 & 29,80 \\
\hline 12.29. & sluggishness & 0,00 & 0,00 & 0,00 \\
\hline 12.30 . & practicality & 6,45 & 14,28 & 7,89 \\
\hline 12.31. & disorder & 0,00 & 0,00 & 0,00 \\
\hline 12.32. & principles & 6,45 & 14,28 & 7,89 \\
\hline
\end{tabular}




\begin{tabular}{|c|c|c|c|c|}
\hline 12.33. & unscrupulousness & 0,00 & 0,00 & 0,00 \\
\hline 12.34 . & purpose & 12,90 & 14,28 & 13,16 \\
\hline 12.35 . & aimlessness & 0,00 & 0,00 & 0,00 \\
\hline 12.36. & emotionality & 41,93 & 28,57 & 40,58 \\
\hline 12.37. & coldness & 0,00 & 0,00 & 0,00 \\
\hline 12.38 . & tenderness & 19,35 & 28,57 & 21,56 \\
\hline 12.39. & rudeness & 3,22 & 14,28 & 5,26 \\
\hline 12.40 . & coquetry & 19,35 & 14,28 & 18,42 \\
\hline 12.41. & tightness & 0,00 & 0,00 & 0,00 \\
\hline 12.42 . & Sexuality, sensuality & 16,13 & 28,57 & 18,42 \\
\hline 12.43. & frigidity & 0,00 & 0,00 & 0,00 \\
\hline 12.44. & Other & 9,68 & 0,00 & 7,89 \\
\hline 13. & \multicolumn{4}{|c|}{ The role of the media text character in the story } \\
\hline 13.1. & Positive & 51,61 & 57,14 & 52,63 \\
\hline 13.2 & Romantic & 22,58 & 14,28 & 21,05 \\
\hline 13.3. & Comic & 9,68 & 14,28 & 10,53 \\
\hline 13.4. & Negative & 3,22 & 14,28 & 5,26 \\
\hline 13.5 . & $\begin{array}{l}\text { Other (for example, the role of } \\
\text { TV } \\
\text { presenter }\end{array}$ & 26,14 & 14,28 & 24,37 \\
\hline 14. & \multicolumn{4}{|c|}{ Influence of media text character in the plot development } \\
\hline 14.1. & Positive influence & 74,19 & 71,43 & 73,68 \\
\hline 14.2 . & Low influence, or no influence & 16,13 & 14,28 & 15,79 \\
\hline 14.3. & $\begin{array}{l}\text { Synthesis of positive } \& \\
\text { negative } \\
\text { influence }\end{array}$ & 6,45 & 14,28 & 7,89 \\
\hline 14.4. & Negative influence & 3,22 & 28,57 & 7,89 \\
\hline
\end{tabular}

\section{Conclusion}

I have developed a classification of indicators of media competence of the audience was quite an effective tool for comparative analysis of the levels of development of media competence of students of the control and experimental groups. This analysis showed the productivity of our models and methodology of media competence of students: the level of media competence of students who have a one-year training course in the framework of media literacy education courses four times higher than in similar indicators in the control group.

Analysis of data (table 17) led us to the following conclusions:

1. Students prefer to choose as a favorite:

1) movies and TV-serials ( $55.26 \%$, while the number of male students who choose this option (85.71 \%) is significantly higher than the number of female students (48.39\%); 2) TV-shows (39.47\% under the dominance of female respondents).

Printing presses, computer games, the internet site as a whole failed to gain more than $8 \%$ of the votes polled.

These data confirm the overall picture that has developed in the contacts with mass media audience: reading is gradually losing its position, the Internet has not yet managed to gain wide circulation, so the audience prefers TV (including watching on television films and series).

2. The most students' preferred genres of media texts have appeared:

1) comedy ( $26.31 \%$ of votes of male respondents are more female);

2) romance ( $23.68 \%$, and this is purely a women's preferences);

3) reality shows and talk shows (by $10.53 \%$ );

4) fiction ( $10.53 \%$, with a predominant number of votes of male respondents - $28.57 \%$ ).

None of the other media genres failed to score more than $6 \%$ of the vote (although the crime drama gives preference to $28.57 \%$ of male students).

As expected, the entertainment dominated among students' favorite genre. Genres that a mass audience are traditionally considered as "heavy" (drama, tragedy, parable, analytical TV program, etc.) are generally not able to score and six percent of the vote. 
3. The vast majority of favorite media characters, according to a sample of the content made by the students, it was men (63.16\%). In this case of male respondents $85.71 \%$ favorite characters men. $58.06 \%$ of respondents allocate characters-men, and $41.93 \%$ - women.

4. As expected, the characters are under the age of 18 and older than 35 years were not very popular in students' audience. Maximum preference was rendered their peers - the age group of 19 to 25 years old (34.21\% of the votes, without significant gender differences in preferences) and a few more characters in the older age group of 26 to 35 years old $(42.10 \%$, are dominated by female voices that psychologically and socially quite understandable, because women often instinctively prefer men with the existing material status and life experience).

5. Racially students choosing favorite characters were unanimous - $84.21 \%$ of the respondents (without gender distinction) preferred media heroes with white skin. However, male respondents were more tolerant of Blacks characters (14.28 \%), while female respondents noted their sympathy to the fabulous, fantastic characters of indeterminate race (for example, from the animated film "Shrek") - $6.45 \%$.

6. Own the level of education (education in high school) significantly influenced the selection of your favorite media characters with higher education $(63.16 \%$, with no gender difference in preferences). However, $23.68 \%$ of respondents liked the characters with secondary education.

7. Similarly, there was the situation with a view of studying / working beloved characters. Most votes received skilled workers (65.79 \%). Media characters like students in the school / university liking mainly male respondents (28.57\%), and only $6.45 \%$ of female respondents. Male respondents also proved more enthusiastic unemployed characters. Paradoxically, the media characters who have low qualifications (10.53\% of the vote) was three times more popular characters, occupying a high position (2.63 \%). Perhaps this apparent traditionally lukewarm attitude of today's youth to senior boss...

8. As expected, the most popular among respondents proved to media characters are bachelors (55.26 \%, while they fell like part of the female students and $71 \%$ of male students). The second most popular characters were married person (36.84 \% at the advantages of female voices). Divorced, widowed and those living in a civil marriage (combined) were able to score only $10 \%$ of the vote. However, here it is worth noting that this kind of preferences (as well as in the previous cases) is dictated by the specific media texts, and there are known to dominate the unmarried and married characters, rather than widowers or divorced...

9. It is clear that the sympathies of students, usually unmarried respondents Were addressed to the bereaved characters (as a whole - $71.05 \%$, but in male students audience, the figure is even more - $85.71 \%$ ). However, a quarter of respondents called the students among their favorite characters and fathers / mothers of one child (among male respondents, this figure did not exceed $15 \%$ ). The popularity of the characters with two or more children in their arms is minimal (3\% to $6 \%$ of the vote).

10. It is also predictable that students prefer visually appealing characters (57.89 \%), or at least - external data medium (31.58 \%). Unattractive by traditional media standards cute characters only $7.89 \%$ of respondents.

11. It is interesting that the characters with sports / athletic figure does not become leaders of student preferences (about $15 \%$ of the vote without a noticeable gender difference in the respondents). Apparently, students are much nicer to sympathize with characters like them at the average body type ( $42.10 \%$ of the vote). However, slender heroes of media texts is also quite popular (34.21\% - with the advantage of female voices) ... With respect to the characters having a weight higher than the average, was designated the tolerance of male respondents $(28.57 \%)$.

12. The most popular media characters traits steel qualities such as optimism (68.42\%), independence (68.42\%), intellectuality (50.00\%), activity, ownership situation (42.10\%), emotional (40 58\%), straightforwardness (36.84 \%), wittiness (34.21\%). About a third of the vote gained such character traits of media characters as kindness, honesty, caring, loyalty, hard work.

This, of course, that such traits as intellectuality, kindness, diligence and loyalty, more votes among female respondents, and in activities - male. Undoubtedly, not all of the above character traits can be unambiguously interpreted as positive. For example, activity and emotion, as I know, does not always go for the good...

But on the whole range of students leaning towards positive media characters. These negative features of the characters, like lying, cowardice, carelessness, passiveness, pessimism, etc. left 
respondents indifferent. However, the $5.26 \%$ allocated in their favorite characters such negative traits as the cruelty and brutality.

13. About half of the respondents (without noticeable gender differences) outlined the role of a character from favorite media text as positive. For $21.05 \%$ of the respondents (with a predominance of female voices) have an important function of the romantic hero. Every tenth respondent singled out a comic character function. And only $5.26 \%$ - negative function (which is identical to the percentage of previously allocated such negative traits of characters, cruelty and brutality). A quarter of respondents said that their favorite characters (usually the TV presenters) does not have a pronounced positive / negative feature in media texts, keeping a sort of neutrality.

14. The majority of respondents ( $73.68 \%$, with no significant gender difference) noted that the characters from their favorite media texts have a positive impact on the development of the plot. And only $7.89 \%$ have identified a negative effect (or both positive and negative effects together).

Thus, analysis of the results of our survey confirmed the general trend of media contacts the student audience - its orientation to entertainment genres of audiovisual media, visually appealing (but medium build), positive, active, unmarried, childless, educated, highly qualified characters (primarily - male characters) aged 19 to 35 years. These heroes are characteristic optimism, independence, intelligence, emotion. They have an excellent command of the life situation and have a positive impact on the development progress of the plot of a media text.

\title{
References:
}

1. Fedorov A.V. (2004). The specificity of media education students of pedagogical universities // Pedagogy. № 4, pp. 43-51.

2. Silverblatt A. (2001). Media Literacy. Westport, Connecticut - London: Praeger, 449 p.

3. Sobkin V.S. (ed.) (2000). Education and information culture. Sociological aspects. Works on the sociology of education. Vol. V. Vol. VII. Moscow, 2000.

\section{УДК 37}

\section{Сравнительный анализ средств массовой информации компетенций уровня студентов}

\author{
Александр Федоров
}

Таганрогский институт имени А.П. Чехова, филиал Ростовского государственного университета экономики, Российская Федерация

Доктор педагогических наук, профессор

Е-почта: mediashkola@rambler.ru

Аннотация. В данной статье проанализированы результаты социологического опроса студентов, касающегося выявления их уровней медиакомпетентности (на базе классификации показателей медиакомпетентности аудитории в качестве эффективного инструмента для сравнительного анализа уровня развития медиакомпетентности студентов в контрольной и экспериментальной группах): уровень медиакомпетентности студентов, которые в течение года обучались в рамках учебного курса по медиаграмотности в четыре раза выше, чем в аналогичные показатели в контрольной группе. Анализ результатов исследования подтвердил общую тенденцию: медийные контакты студенческой аудитории основаны на ее ориентации на развлекательные жанры аудиовизуальных, визуально привлекательных медиа; на положительных, активных, не состоящих в браке, бездетных, образованных, высококвалифицированных персонажей (в первую очередь - мужчин) в возрасте от 19 до 35 лет. Этим персонажам отличаются оптимизмом, независимостью, умом, эмоциональностью, и они оказывают положительное влияние на развитие сюжета медиатекста.

Ключевые слова: социологический опрос, анализ, средства массовой информации, медиа, медиатексты, медиаграмотность, медиакомпетентность, студенты. 